International Journal of Multidisciplinary Education and Research

ISSN: 2455-4588

Impact Factor: RJIF 5.12

www.educationjournal.in

Volume 3; Issue 2; March 2018; Page No. 52-55

\title{
Value of java philosophy in novel "Pasar" Kuntowijoyo works on character education
}

\author{
Slameto \\ University of Muslim Nusantara Al-wasliyah, Indonesia
}

\begin{abstract}
Pasar novel written by Kuntowijoyo in 1971 is one of the novels that try to raise the reality of people's life at that time, especially Javanese society. This novel is able to describe the social condition of the society. The story in Pasar novel is really simple. The storyline is a Javanese society, represented by a sub-district, Gemolong District. People who play in it was not much. However, it cann't be denied, the novel is full of meaning, especially about the values of Java which has been considered very noble. These Javanese values concern the issue of attitude, soul, and culture. Kuntowijoyo is indeed a Javanese. As a writer and culturalist, he is able to integrate the cultural reality that takes place in his society by cleverly composing the word into a compelling novel. Without impressed patronizing, the reader seemed to be invited to remember and reflect on the Javanese values that began to fade left by the Javanese themselves. Javanese values revealed in this Pasar novel are values that should be held firm and become the basis for the Javanese in navigating his life. These values include (1) self-awareness (as best a deed is to see oneself) as students must have an honest character, tolerance and discipline, (2) a life of samadya, honest, willing to sacrifice, answer, also about the secrets of life, and so on.
\end{abstract}

Keywords: java philosophy, character education

\section{Introduction}

As with oral literature, literature in written form (in this case a novel) can also be treated as a material object, either as an "entrance" to understanding a particular culture, or as one of the cultural elements being studied. Through searching on the dimensions and anthropological implications of literary texts or, in short, by developing literary anthropology as a research paradigm, it may not be possible to find only certain interpretation models, but also to obtain the possibility of answering questions about the cultural issues of society certain.

One aspect of culture that interests the observers of literary anthropology is the image of archetypes and/or primordial images. Historically, the characteristics of archetypes included in the analysis of literary works went through two lines. First, through Jungian analytical psychology, second through cultural anthropology. The first tradition, tracing the psychological traces, the recurring typology of experience, as racial awareness, such as myths, dreams, fantasies, and religions, includes literary works. The second tradition explores the elemental patterns of myth and ritual that are generally contained in legends and ceremonies. In literature this phenomenon appears through the description of the narrative patterns, the typology of the characters (Ratna, 2004).

Myth is an anonymous story rooted in primitive culture. If at first myth is defined as a simple and primitive imagination to compose a story, then in the sense of modem myth is the structure of the story itself. Barthes (2004) mentions that myth is a type of speech, everything can be a myth as long as it is presented by a discourse. Literary works are definitely not myths, but as aesthetic forms, literary works are a manifestation of the myth itself.
The value and philosophy of Java which is the foundation of this research should be interpreted as a knowledge of the Javanese mythical world. Some of the myths are a myth to the feasibility of individual life in a society that represents the myth. The most prominent Javanese myth is the wayang story originating from the epic Mahabharata and the Ramayana. Perhaps if further traced the mythical world of Javanese originated and may be rooted in Hindu mythology that brings the tradition of the epoch's second story.

In terms of the culture that nurtures, Kuntowijoyo lives in the culture of Yogyakarta. As Wangsitalaja (Anwar, 2007) says, both cultures are equally kejawen, but have a number of differences behind the contradictions. Yogyakarta culture is "all-round potent-masculine-active", a thick cultural culture that permeates the works of Kuntowijoyo, berdialektika with Western culture and intensive Islamic civilization cultivated and lived.

The Indonesian literature itself, which first exhibited a strong Dutch literary influence, as seen in the work of the authors of the Balai Pustaka and Pujangga Baru Forces, then shows the broader palate; while the influence of Islamic literature through Arabic though not prominent remains a basic tone, except for some authors like Hamka. Life, beliefs, ideals contained in Islam, will easily be found in various literary works Balai Pustaka, even literary works of writers of New Poets, and Force '45. Although for a long time this Islam did not arise consciously and menonojol, but he remains clearly the background of almost every literary work written. In the last two or even three decades, it appears that Islam has emerged more consciously in Indonesian literary life as seen in the works of Bahrum Rangkuti, A. A. Navis, Danarto and Kuntowijoyo.

The diversity of Indonesia's national literature does not show a 
mosaic based on religion alone, but also on the basis of cultural diversity and art. The life of each tribe that has different customs, different types of art, gives the possibility to enrich the beauty of the mosaic.

Cultural diversity is found in Kuntowijoyo novels. Kuntowijoyo's novels are not the kind of literary works that belittle the idea or message to be conveyed. The idea and the message rolled into a realist narrative network that seeks to explore the meaning of life in the dynamics of history and socio-cultural change of society. In addition, Anwar (2007) points out that Kuntowijovo's work is said to be the work in which the "vision of the narrative" is played.

Kuntowijoyo is a figure that shows the reality of Javanese culture. Judging from his educational background he is a historian. However, his works show that he is also a scholar, a cleric, and a humanist. The title is inherent because it contributes greatly to other fields such as literature, social sciences, and the integration of religious knowledge and knowledge with the concept of Islamic scholarship. In talking about the flow of thought that he expressed, can be discussed from the literature that he scratched on his works. Kuntowojoyo reflects on his philosophical ideas through his transcendental (religious) and prophetic works (emphasizing human freedom). Transcendental literature can be seen in his novel Sermon on the Mount (1976), American dreams, forbidden flowers, dogs stormed graves, and a collection of poems entitled Suluk Awang-Uwung. Meanwhile, the prophetic literature namely, Pasar, Mantra Penjinak Snake, Makhrifat Leaves Makhrifat Leaves, and the last Wasripin and Satinah. Novel Wasripin and Satinah (2003) is the last work of Kuntowojoyo before the meningo enchepalitis virus claimed his life on February 22, 2005.

Kuntowojoyo's novels to be analyzed on this occasion are Pasars (1972, Reboot 1994 \& 2002), Mantra Pejinak Ular (2000), and Wasripin and Satinah (2003). The richness of the Javanese cultural problems in the literary work has led to the author's interest in researching Javanese mythology in Kuntowojoyo's novels.

\section{Method}

Data collection in this study using literature study techniques. This technique is used because the data source that is written more dominant. The literature study technique is the research or investigation of all books, essays, and writings on a field of science, topics, symptoms or events (Moeliono, 1990). Accordingly, researchers will conduct an analysis of the main data, ie novels Kuntowijoyo. To assist and supplement the main data, we collect books related to this research.

After the data collected, then processed using content analysis techniques. Content analysis is used by researchers to uncover, understand, and capture messages of literary works. Such an understanding relies on rigid literary interpretations. That is, researchers have built a concept that will be revealed, just entered the literary work.

In the process of data processing performed the following steps:

1. Researchers read Kuntowijoyo novels which become the object of research repeatedly in order to gain a deeper understanding. Reading hemeneutik takes place in two levels (level). First, read the heuristics, ie read on the basis of an understanding of the language convention. Second, read hermeneutics, ie searched implied meaning. This interpretation requires a hanja code, cultural code and literary code. Thus, hermeneutic reading allows the giving of distinctive, hervariated, and profound meanings.

2. The researcher marks and focuses the interpretation on objects related to Javanese mythology, philosophy, and cultural values. Data analysis is not done per data source, but per item problem has been formulated. Thus, data analysis is done in a holistic and holistic manner (comprehensive).

3. The researcher then reinterpret all the identified and specified data to find the unity, unity, and inter-ordinal relationships so as to gain complete knowledge of the issues in this study.

To be understood in the study of Java Philosophy Value in Kuntowijoyo's novel "Pasar" the need for research instruments that we will give to students, among others: (1) Look for Javanese philosophy in the novel "Pasar"? (2) From the philosophy interpret what the meaning contained in it! (3) Philosophy is included to the character education of students according to Diknas (there are 18 characters) which one. Explain!

\section{Result}

Table 1: Character education in the value of Javanese philosophy in Kuntowijoyo's novel "Pasar"

\begin{tabular}{|c|c|c|}
\hline $\begin{array}{l}\text { Character } \\
\text { Building }\end{array}$ & Javanese Philosophy & Meaning \\
\hline Religious & $\begin{array}{c}\text { "Be patient", everything will be } \\
\text { sorted }\end{array}$ & $\begin{array}{l}\text { we must be patient in doing something difficult like the word of God that says that God is with } \\
\text { those who are patient because God will help us in the order that we will not miss and fit our } \\
\text { needs. }\end{array}$ \\
\hline Honest & $\begin{array}{l}\text { Everything good for life } \\
\text { "honest, faithful, polite, self- } \\
\text { knowledge" }\end{array}$ & $\begin{array}{l}\text { in living a life to be honest, do not like to lie to others. Be faithful to where we work, do not } \\
\text { defame others. Courtesy to anyone good to the old, young, know or not with the person. Know } \\
\text { where we stand as the proverb "Where the earth is rested there the heavens in junjung", } \\
\text { "Another grasshopper grassland", do not we act as we are not in accordance with the custom } \\
\text { and adab area/location. }\end{array}$ \\
\hline Tolerance & $\begin{array}{l}\text { "Fellow titah", fellow beings } \\
\text { must be equal }\end{array}$ & $\begin{array}{l}\text { fellow beings in the world created by God whether human, animal, male, female must be } \\
\text { treated equally all rights }\end{array}$ \\
\hline Discipline & $\begin{array}{l}\text { Since when did you become a } \\
\text { "Gemolong?" }\end{array}$ & People who are not dyed \\
\hline
\end{tabular}




\begin{tabular}{|c|c|c|}
\hline Hard work & "We must try our own" & $\begin{array}{l}\text { We must struggle with the power of self to achieve the ideals and just as in the struggle for } \\
\text { Indonesian independence with the power of the nation. }\end{array}$ \\
\hline Creative & $\begin{array}{l}\text { All that action must be thought } \\
\text { of }\end{array}$ & before doing something should be thought through first or in the first rupture inside \\
\hline Independent & "Jer basuki mawa beya" & do not expect results, no future prosperity without sacrifice today. \\
\hline Democratic & $\begin{array}{l}\text { Do not "adigung", mentang- } \\
\text { mentang big people }\end{array}$ & $\begin{array}{c}\text { if being a person in power / lead should not be characterizing such power by acting carelessly } \\
\text { and respect everyone. }\end{array}$ \\
\hline Curiosity & $\begin{array}{c}\text { More "eat salt" live from the } \\
\text { pack of sub-district/police chief }\end{array}$ & the older feel more bitter sweetness of life \\
\hline $\begin{array}{c}\text { Spirit of } \\
\text { nationality }\end{array}$ & "Justice must walk" & justice must be carried out at the forefront for everyone \\
\hline $\begin{array}{l}\text { Love the } \\
\text { homeland }\end{array}$ & $\begin{array}{l}\text { What is the meaning of a drop } \\
\text { of water in the vast ocean? }\end{array}$ & be courageous amongst others \\
\hline $\begin{array}{c}\text { Appreciate } \\
\text { achievement }\end{array}$ & $\begin{array}{c}\text { Simultaneously shows the noble } \\
\text { spirit }\end{array}$ & a good person reflects a good mind even if he does not do something good \\
\hline \begin{tabular}{c|c|} 
Friendly/ \\
Communicative
\end{tabular} & $\begin{array}{l}\text { Know, the man is not living } \\
\text { alone }\end{array}$ & people / humans cann't live alone, without others because people / people need each other \\
\hline Cinda is peaceful & $\begin{array}{l}\text { "Looking for a new, peaceful } \\
\text { way of life" }\end{array}$ & did not like the riots that were created in Mr Mantri Market \\
\hline Like to read & $\begin{array}{c}\text { It is fortunate that he became a } \\
\text { Javanese, read the letters, and } \\
\text { the story of the prophets as } \\
\text { well! }\end{array}$ & $\begin{array}{l}\text { Every person must be diligent in reading not only the Javanese alone, but at this Market } \\
\text { character Mantri in characterized as a Javanese. }\end{array}$ \\
\hline $\begin{array}{l}\text { Environmental } \\
\text { care }\end{array}$ & $\begin{array}{c}\text { Stretch the world around you, } \\
\text { then it will incarnate beautifully } \\
\text { before your eyes }\end{array}$ & $\begin{array}{l}\text { Love and keep nature around you then nature will give the beauty that makes your mama does } \\
\text { not blink at it. }\end{array}$ \\
\hline Social care & $\begin{array}{c}\text { To be noticed is the fate of the } \\
\text { destitute small people }\end{array}$ & who really need to be assisted is a hard person (poor) \\
\hline Responsible & $\begin{array}{l}\text { A virtuous person is a } \\
\text { responsible person. }\end{array}$ & virtuous living beings must be responsible to other created beings, for that is a mandate \\
\hline
\end{tabular}

\section{Conclusion}

1. Novel Pasar written by Kuntowijoyo in 1971 is one of the novels that try to lift the reality of people's life at that time, especially the Javanese people. This novel is able to describe the social condition of the society. The story in Pasar novel is really simple. The storyline is a Javanese society, represented by a sub-district, Gemolong District. People who play in it was not much. However, it can not be denied, the novel is full of meaning, especially about the values of Java which has been considered very noble. These Javanese values concern the issue of attitude, soul, and culture.

2. Kuntowijoyo is a Javanese. As a writer and culturalist, he is able to integrate the cultural reality that takes place in his society by cleverly composing the word into a compelling novel. Without impressed patronizing, the reader seemed to be invited to remember and reflect on the Javanese values that began to fade left by the Javanese themselves. The Javanese values revealed in this Pasar novel are values that should be firmly held and become the basis for the Javanese in navigating their lives.

3. These values include (1) self-awareness (as best as the act is to see oneself) as students must have an honest character, tolerance and discipline (Page 10), (2) a life of samadya, honest, willing to sacrifice, responsible, also about the secrets of life, and so forth.

4. In the midst of the swift wave of social change that occurred in the community, Mr. Mantri still holds the attitude of noble character. He is always trying to live his life with all the characteristics and qualities possessed by God Almighty. Mr. Mantri prioritizes honesty and loyalty in performing his duties. He also does not want to prejudice others. Not hating others, because the wrong is not the person, but the deed. When Kasan Ngali fell, he showed no joy. For Mr. Mantri, as a Javanese, it is not good to laugh at the misfortune of others. In fact, it is very clear that Kasan Ngali has been hostile to him.

\section{References}

1. Anderson Benedict RO'G. Mu'ologi dan Toleransi Orang Jawa. Terj. Revianto B. Santoso dan Luthfi Wulandari. Yogyakarta: Jejak, 2008.

2. Anwar Wan. Danarto: Karya dan Dunianya. Jakarta: Grasindo, 2007.

3. Bleicher Josef. Herineneutika Kontemporer. Terj. Ahmad Norma Permata Yogyakarta: Fajar Pustaka Baru, 2003.

4. Ciptoprawiro Abdullah. Filsafat Jawa. Jakarta: Balai Pustaka, 2000.

5. Dananjdaja James. Folkior Indonesia. Cet. VI. Jakarta: Pustaka Utama Grafiti, 2002.

6. Djojosuroto Kinayati. Filsafat Bahasa. Yogyakarta: Pustaka Book Publisher, 2007.

7. Eliade Mircea. Mitos Gerak Kembali yang Abadi. Kosmos dan Sejarah. Cetakan Pertama. Yogyakarta: Ikon Teralitera, 2002.

8. Endraswara Suwardi. Metodologi Penelitian Sastra Epistemologi, Model, Leon, dan Aplikasi. Yogyakarta: Media Pressindo, 2008.

9. Hadi Abdul WM. Herineneutika, Estetika, dan Re/igiusitas. Esai-Esai Sastra Sufistik dan Seni Rupa. Cetakan Pertama. Yogyakarta: Matahari, 2004.

10. Hoed Benny H. Semiotika dan Dinamika Sosial Budayu. 
Depok: Fakultas Ilmu Pengetahuan Budaya UI, 2007.

11. Kamaruzzaman. Relasi Islam dan Negara: Perspektif Modemis \& Fundamentulis. Cetakan Pertama. Magelang: Indonesiatera, 2001.

12. Kieden Ignas. Sastra Indonesia dalam Enam Pertanyaan. Esai-Eai Sastra dun Budava. Jakarta: Pustaka Utama Grafiti, 2004.

13. Koentjaraningrat. Pengantar Ilmu antropologi. Jakarta: Rineka Cipta, 2002.

14. Minsarwati Wisnu. Mitos Merapi \& Kearfan Ekologi: Menguak Bahasa Mitos dalam Kehidupan A las varakat, Jawa Pegunungan. Yogyakarta: Kreasi Wacana, 2002.

15. Nurelide. Meretas Budaya Masyarakat Batak Toba dalam Cerita Sigalegale dalam Jumal Kebahasaan dan Kesastraan Medan Makna. 2006, Vol 5/2006 hal 46-61. Medan: Balai Bahasa.

16. Palmer Richard E. Hermeneutika: Teori Baru Mengenai Interpretasi. Yogyakarta: Pustaka Pelajar, 2003.

17. Ratna Nyoman Kutha. Teori, Metode, dan Teknik Penelitian Sastra: dan Strukiuralisme hingga Postrukturalisme. Yogyakarta: Pustaka Pelajar, 2004.

18. Rokhman Muh, Arif. Sastra Interdisipliner: Menyandingkan Sastra dan Disiplin Ilmu Sosial. Yogyakarta: Qalam, 2003.

19. Rosliani. Citra Manusia Indonesia: Mitologi Suku Asli Sumatera Utara: Laporan Penelitian. Medan: Balai Bahasa, 2006.

20. Sani. Sastra Profetik: Mengenal Sastra Danarto. Dalam Tulisan Sani, Jakarta, 2008.

21. Setyodarmodjo Soenarko. Menggali Filsafat dan Budaya Jawa. Jakarta: Prestasi Pustaka, 2007.

22. Sikana Mana. Teori Sastera Kontemporer. Selangor: Pustaka Karya, 2008.

23. Suseno Franz Magnis. Etika Jawa. Sehuah Analisa FalsajI tentung Kebjak.sanaan Hidup Jawa. Jakarta: Gramedia, 2003.

24. Susetya Wawan. Ngelmu Makrilit Kelawen. Tradisi Jawa Melepaskan Keduniawian Menggapai Kemanunggalan. Yogyakarta: Narasi, 2007.

25. Syaifuddin $\mathrm{Hj}$, Wan Mahzim. Mantera dan Upacara Ritual Masyarakat Melayu Pesisir di Sumatera Utara: Kajian Tentang Fungsi dan Nilai-Nilai Buduya. Malaysia: Universiti Sains Malaysia, 2005.

26. Thomson Jhon B. Filsafrit Bahusu dun Rermeneutik. Ten. Abdullah K. Affandi. Surabaya; Visi Humanika, 2005.

27. Umri Shafwan Hady. Mitos-Realitas dalam Novel Janji Gintamini dalam .Jumal Jim iah Kebahasaan dan Kesastraan Medan Makna. Nomor 3/2006 hal, 2006, 4347. Medan: Balai Bahasa. 